\title{
Article
}

\section{A Global PSS Framework for Sustainable B2B Partnership}

\author{
Sandra S. Graça (1)
}

\section{check for}

updates

Citation: Graça, S.S. A Global PSS Framework for Sustainable B2B Partnership. Sustainability 2021, 13, 3066. https://doi.org/10.3390/ su13063066

Academic Editor: Jihwan Lee

Received: 30 January 2021

Accepted: 9 March 2021

Published: 11 March 2021

Publisher's Note: MDPI stays neutral with regard to jurisdictional claims in published maps and institutional affiliations.

Copyright: (C) 2021 by the author. Licensee MDPI, Basel, Switzerland. This article is an open access article distributed under the terms and conditions of the Creative Commons Attribution (CC BY) license (https:/ / creativecommons.org/licenses/by/ $4.0 /)$.
Collegium of Comparative Cultures, Eckerd College, Saint Petersburg, FL 32711, USA; gracass@eckerd.edu

\begin{abstract}
Committed Business-to-Business (B2B) relationships are linked to sustainable business partnerships and greater profitability. As competition increases, suppliers must seek to differentiate by shifting the focus of their offerings from the product to services that contribute to create additional value to buyers. This empirical research proposes a product-service system (PSS) framework within the context of a relationship marketing (RM) model tested across a sample of United States (US) and Brazilian buyers. The study examines the impact of value-added benefits on building sustainable B2B partnerships. Results demonstrate that a firm's servitization strategy that delivers both functional and social benefits fosters greater information exchange and mutual cooperation, which in turn contributes to increase buyer's trust in, satisfaction with and commitment to a supplier. Despite some noted differences found in the commitment-building process, results show the importance that additional services have on promoting long-term, sustainable B2B partnerships across countries in distinct stages of economic development.
\end{abstract}

Keywords: functional and social benefits; PSS; relationship marketing; satisfaction; communication; commitment; trust; cooperation; sustainable B2B partnerships

\section{Introduction}

As competition in B2B settings and customer expectations continue to increase, firms are seeking ways to differentiate by providing additional value to buyers that goes beyond the product offerings. There is greater emphasis being placed on servitization, the process of adding services to a company's main offerings. These additional services are unique value-added activities that are more difficult to replicate and consequently become sources of competitive advantage for the firm [1,2]. Therefore, companies are adopting product service-systems (PSS) as a holistic approach to their business models. PSS is regarded as a "special case of servitization" [3] with a focus on value-added services that allows firms to transition from solely providers of products to providers of solutions [4]. From a strategic perspective, these additional services, or value-added activities, allow companies to compete with more unique bundles that deliver differentiated solutions to customers. With a focus on the customer, unique PSS is essentially a marketing strategy for firms to sustain competitiveness. From a financial perspective, companies benefit from greater profit margins afforded by these value-added activities without the need to compete solely based on cost-related benefits [3].

The adoption of PSS supports general global trends as customers seek to form longterm partnerships with suppliers that prioritize solutions that can directly contribute to positive performance outcomes [5]. The trend towards the adoption of servitization and PSS models is also driven by the availability of growing complexity of business models and increasing desire of buyers for co-creation of value [6]. Besides the importance of emphasizing solutions versus products, the shift to focus on bundle offers is also driven by a greater focus on outcomes versus outputs and the importance of business relationships and network partnerships [1,2,7]. Although additional services are commonly deployed under relational exchanges within the context of relationship marketing models, "the effect that servitization has on buyer-supplier relationships" [8] is underexplored. In fact, the concept of "the provision of integrated solutions" is more effectively examined under the 
context of relational versus transactional exchanges. There are few studies, if any, that examine the impact of PSS on RM outcomes such as trust, performance satisfaction and commitment, therefore, bridging the two literatures is not only appropriate, but a needed contribution of this research.

Most PSS studies to date examine common servitization strategies that are functional in nature (e.g., delivery, consultation, repair, maintenance) and focus on transaction cost theory (TCT) to explain firm behavior. Some studies have explored the role of relational factors and social benefits $[7,9]$ in servitization and PSS models, but the investigation within the context of buyer-supplier relationship and RM through the lens of social exchange theory (SET) is warranted. The inclusion of additional services alone is not always effective. Common additional services such as those related to training, delivery, maintenance and repair have become basic services offered by various competing firms and "don't provide additional excitement for the customer" [2]. These 'basic services' are quite easy to imitate and cannot provide a competitive advantage in the long-run. Reim, Parida and Örtqvist note that "when companies pursue PSS implementation strategies, they add either service or product elements to their operations in different ways, which results in different outcomes" [10]. Therefore, a shift in PSS focus that incorporates product/service offerings, or bundle of solutions, that also provide unique social benefits to buyers beyond functionality can further distinguish a firm's offering from their competitors and greatly contribute to partnership longevity.

Finally, the trend towards integrated solutions and PSS business models is global. Despite being originally adopted by firms in more developed countries, suppliers in emerging markets are seeking ways to move up the value chain as their markets continue to develop. As the importance of emerging markets continue to grow, a comparative global study that include countries in distinct stages of economic development is also needed. Studies that examine the generalizability of PSS models in both developed and emerging market contexts are scarce, but necessary. Therefore, the purpose of this research is to propose a global framework of functional and social benefits to promote sustainable buyer-supplier relationships within the context of one developed (U.S.) and one emerging market (Brazil). The research contributes to the PSS literature in three ways:

First, it links the PSS and RM literatures by empirically examining the impact of servitization strategies on building sustainable buyer-supplier partnerships through the lens of SET. Second, the study examines both functional and social benefits as value-added activities and their contributions to increasing relationship capital. Third, it provides a more global perspective to PSS by testing the model in two economically distinct country contexts (US = developed market and Brazil = emerging market). The proposed global PSS framework for sustainable B2B partnerships is depicted in Figure 1.

\begin{tabular}{|c|c|c|}
\hline $\begin{array}{l}\text { Servitization Strategies } \\
\text { Value-Added Benefits }\end{array}$ & $\begin{array}{l}\text { Relationship Connectors } \\
\text { Supporters of PSS Models }\end{array}$ & $\begin{array}{l}\text { Relationship Capital For } \\
\text { Sustainable Partnerships }\end{array}$ \\
\hline \begin{tabular}{l}
\multicolumn{1}{c}{ Social } \\
Benefits \\
- Friendship \\
- Personal Relationship \\
- Time \& Company
\end{tabular} & $\begin{array}{c}\text { Information } \\
\text { Exchange } \\
\text { - Seek Advice/suggestions } \\
\text { - Joint Goal-setting/planning } \\
\text { - Keep partner well-informed }\end{array}$ & $\begin{aligned} & \text { Benevolent Trust } \\
& \text { - Buyer's Welfare } \text { - Buyer's Best Interest } \\
& \text { Supplier Performance }\end{aligned}$ \\
\hline \begin{tabular}{l}
\multicolumn{1}{c}{$\begin{array}{c}\text { Functional } \\
\text { Benefits }\end{array}$} \\
- Convenience \\
- Time-savings \& Advice \\
- Better Purchase Decisions
\end{tabular} & $\begin{array}{c}\text { Mutual } \\
\text { Cooperation } \\
\text { - Buyer Helps Supplier } \\
\text { - Supplier Helps Buyers }\end{array}$ & $\begin{array}{l}\text { Buyer Commitment } \\
\text { - Loyalty and Allegiance } \\
\text { - Regard Supplier as "Part } \\
\text { of the Family" }\end{array}$ \\
\hline
\end{tabular}

Figure 1. Global PSS framework for sustainable B2B partnerships. 
Next, the theoretical background on PSS is discussed along with the inclusion of functional and social benefits as additional valued added activities and as servitization strategies. Then, the linkage between PSS and RM is developed through the lens of SET, followed by a discussion on the relationship connectors and dimensions of relationship capital that foster sustainable partnerships. Hypotheses are developed and a relationship model is presented and tested, followed by a discussion on the methodology applied and results. Finally, the implications of the study and future research possibilities are included.

\section{Theoretical Background}

\subsection{Product Service Systems}

The concepts of servitization and PSS are closely related and referred to as a firm's addition of services to their main products with the purpose of creating additional value to customers [11]. The concept has evolved and today servitization is considered essential for all companies regardless of the nature of their main offering (e.g., product vs. service) [10]. The combination of both tangible products and services is regarded as a unique bundle or "single offer" [3] that identify a firm's unique value proposition. In turn, this unique single offer supports buyers' increasing demand for suppliers' to provide a "seamless offer" or integrated solutions that is personalized and can facilitate their operations to improve performance outcomes $[8,12]$ and as a strategic response to "increasing competition, stagnating markets and eroding margins" [13]

The literature on servitization thus far has focused primarily on the benefits that manufacturing firms receive from providing customers with additional functional services such as installation, maintenance and support, distribution and training [1]. Despite the importance of social benefits in RM and PSS, few studies have examined social attributes as valued added benefits and as servitization strategies to build sustainable partnerships. Servitization, as noted by Sakyi-Gyinae and Holmlund, "is about value and the measurable benefits that will accrue to help the customer achieve their own business goals" and these benefits can include social attributes such communication and relationship-building [7]. In addition, the "delivery of services is more easily achieved through relational rather than transactional exchange" [8], thus SET offers a more holistic approach to examining new PSS frameworks and their relationship marketing outcomes.

\subsection{RM and SET-Relational Exchanges}

Social Exchange Theory has been the primary theory to explain buyer-supplier relational exchanges [14] because the focus is on the strength of the relationship. In essence, partners build relational norms over time that serve as a contract or guide for partner interaction. The main premises of SET is that exchange interactions can result in economic and social outcomes that are mutually beneficial to business partners. The relationship marketing literature, in particular, highlights the interdependence of partners evident in outcomes such as trust and commitment. RM refers to the establishment, development and maintenance of successful relational exchanges [15]. RM is best explained by SET and is supported by relationship connectors such as information exchange and cooperation [8]. In order to build sustainable partnerships, RM also demonstrates the importance of both functional and social relationship benefits that suppliers offer to buyer's in B2B context [16-18]. These benefits create mutual dependencies and increase "customer's willingness to develop relational bonds" [19] with a supplier. Functional benefits refer to the advice that suppliers provide to buyers to help them make better decisions and other convenient and time-savings services distinctive to the supplier. Social benefits represent the degree of friendship of the relationship, the close ties between partners and the value that the buyer receives from the personal time spent with the supplier [16]. Social benefits are interpersonal, co-created with the customers and as such they are highly personal and unique in nature and require high levels of interaction between partners. Social interaction, setting goals and planning together allow for more efficiency and contribute to increase meaningful and cooperative communication exchanges between partners [20]. Together, 
these functional and social benefits support the emotional bond developed by business partners overtime and serve to connect buyer-suppliers further by requiring a high degree of personal interaction, information exchange and mutual cooperation.

\subsection{Relationship Connectors}

The nature of buyer-seller relational exchange requires high levels of collaborative exchange and cooperative norms to be successful. Rooted in SET, Cannon and Perreault refer to these two relational factors as "connectors" that bond buyer-suppliers together and "reflect the manner in which two partiers interrelate and conduct commercial exchange" [21]. Information exchange is the extent to which partners will share information, seek the advice and suggestions from each other and set goals together [20]. It is referred to as the glue that holds relationships together and an essential factor in partnership development Mutual cooperation refers to the degree to which buyers and suppliers help one another and work together to achieve mutually beneficial goals [22]. Strategic collaboration is key to develop trusted and committed B2B relationships. High levels of information exchange has been found to greatly increase a buyer's satisfaction with the supplier's performance; and combined with mutual cooperation, they are found to increase trust and commitment $[12,15,21]$. Karatzas, Kaczor and Gregus, for example, found that both cooperation and information exchange play a significant role in manufacturer-supplier relationship to facilitate service performance [23]. Together, these two connectors are regarded as links between "coordination and numerous organizational outcomes" [24] and warrant further examination as key mediators in RM and PSS models.

\subsection{Relationship Capital for Sustainable Partnerships}

Sustainability in B2B relationships is a desired state as it lowers cost and increases profitability, especially within a global B2B context. Through time, successful exchanges build relationship capital and foster relationship longevity [25] characterized by high degrees of benevolent trust, performance satisfaction and commitment. Together they measure the level of relationship capital or the "sticky nature of the relationship that constitutes a realistic alternative to egotistical power and control" [26]. Benevolent trust refers to the degree of benevolence or level of goodwill of the supplier towards the buyer's welfare [27]. Performance satisfaction refers to the buyer's evaluation of the supplier's performance in terms of meeting desired results and expectations. Commitment is the degree in which a buyer's affection towards the supplier contributes to partnership allegiance and loyalty [28].

\subsection{Hypotheses Development}

A number of RM studies report high inter-construct correlations between relationship benefits and information exchange and mutual cooperation $[15,19]$. The interpersonal nature of developing social ties between partners while at the same time facilitating tasks to be completed require high levels of information exchange and the establishment of cooperative norms [18].

Significant correlations between relationship benefits with the relationship capital outcomes (trust, satisfaction and commitment) have been established in past studies and reported in Palmatier et al.'s meta-analysis of RM [19]. In addition, there is evidence of strong correlations between relationship benefits and the relationship connectors (mutual cooperation and information exchange) found in other studies [18,29]. Although traditional RM models include both relationship benefits and communication as direct antecedent to trust and commitment, the empirical examination of the reversed relationship is warranted. As a departure from the traditional direction of the relationship usually tested in RM models and to present a framework that is more aligned with the PSS literature, this study examines the effect of relationship benefits on outcomes via the mediating effects of two key relationship connectors proposed by Cannon and Perreault [21]. As such, the delivery of functional and social benefits are expected to contribute to increase the exchange of 
information and mutual cooperation between buyers and suppliers. Therefore, we propose the following for the US and Brazil:

H1: Functional benefits will increase supplier's information exchange;

H2: Functional benefits will increase mutual cooperation;

H3: Social benefits will increase supplier's information exchange;

H4: Social benefits will increase mutual cooperation.

Information exchange is found to increase benevolent trust in various studies of RM [19] and buyer-supplier relationship [30]. The reciprocal nature of information exchange serves to demonstrate a party's good intentions encouraged by the continuous feedback and suggestions for improvement among exchange partners [31]. Information exchange also involves the sharing of critical, often proprietary information [20]. Sometimes referred to as two-way communication, information exchange is found to increase a buyer's satisfaction in the supplier's performance [32]. Therefore, the following hypotheses are proposed for the US and Brazil:

H5: Information Exchange will increase buyer's trust in supplier's benevolence;

H6: Information Exchange will increase buyer's satisfaction in supplier's performance.

Mutual cooperation has also been highly correlated with trust $[15,25]$ and commitment [33]. Although, the relationship between cooperation and trust is likely to be bidirectional, increased mutual cooperative behavior signals to a buyer that a supplier has their best interest in mind. Similarly, greater supplier cooperation demonstrates goodwill intentions and support the commitment-building process. Despite the universal importance of cooperation in fostering commitment under various B2B contexts, the relationship is expected to be stronger in more developed markets with supportive formal institutions where public trust is high [33,34]. Mutual cooperation flourishes in 'safe' business environments and since buyers in developed economies place greater focus on efficiency and operate under an institutional context designed to decrease business opportunism [35], the following hypotheses are proposed:

H7: Mutual cooperation will increase buyer's trust in supplier's benevolence;

H8a and H8b: (a) Mutual cooperation will increase buyer's commitment to a supplier, (b) as such that the relationship will be stronger in the US.

Trust has been widely studied and shown to contribute to increase commitment in relational exchanges and to be the catalyst in RM $[15,22,36]$. Especially in emerging markets with ineffective and unsupportive formal institutions, trust is catalyst for long-term B2B relationships to develop and has been found to be stronger in Brazil [18]. Therefore, the following hypotheses are proposed:

H9a and H9b: (a) Benevolent trust will increase buyer's commitment to supplier; (b) as such that the relationship will be stronger in Brazil.

Finally, we propose that the effects of the antecedents (e.g., functional and social benefits on outcomes (performance satisfaction and commitment) are mediated by the two key relationship connectors (information exchange and mutual cooperation) proposed by Cannon and Perreault [21]. Therefore, we expect the following:

H10a and H10b: (a) Information exchange mediates the effects of functional and social benefits on performance satisfaction and (b) mutual cooperation mediates the effects of functional and social benefits on commitment.

The hypothesized model is presented in Figure 2. 


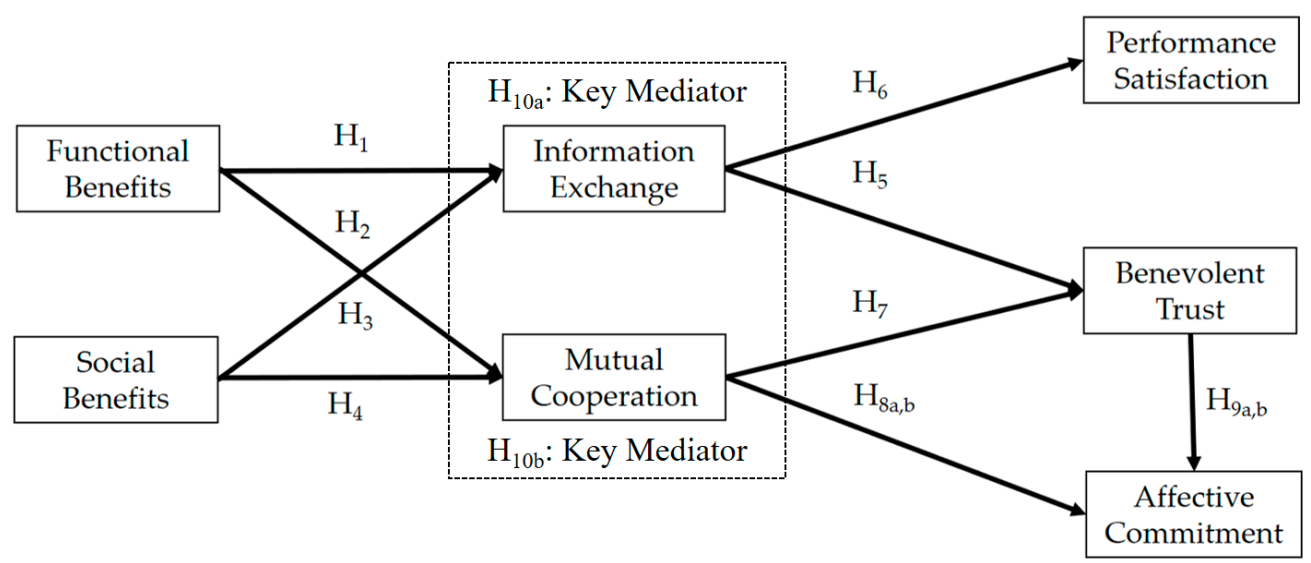

Figure 2. Hypothesized model.

\section{Materials and Methods}

A sample from the US as a developed and one from Brazil as an emerging market were selected to provide a comparison of the model between countries in distinct stages of economic and institutional development. Special measures and standard procedures were followed to assure an acceptable level of measurement equivalence that would allow for cross-cultural sample comparisons [37]. Recommended guidelines to address comparability of participants and sampling design, measure reliability and validity (e.g., normative, semantic, conceptual equivalence, configural and metric equivalence) and data analysis design were also followed [38-41]. A summary of the cross-cultural methodology approach is included in Table 1.

Table 1. Cross-cultural methodology approach.

\section{International Research Issue}

Comparability of Participants Sample Design

\section{Standards and Design Approaches Used in This Study}

- $\quad$ Respondents had similar relationship to the constructs in the study. Same instructions were given to all participants in each country

- $\quad$ Respondents were similar in job responsibility, group membership and business objectives

- $\quad$ Participants within country were drawn from the same geographic location with similar sociodemographic characteristics
Normative, Semantic and Conceptual Equivalence Measurement Design
All concepts and measures were equally accepted and understood by participants in each country group

- $\quad$ Measures were derived from existing studies and had been widely validated in the literature review

- $\quad$ Bi-cultural and bi-lingual author translated and used professional translators to back-translate

- Practitioners and experts in the field were consulted. Measures were pretested to determine if the questions were understood in both country contexts
Configural and Metric Equivalence Factor

Covariance Invariance

Measurement Design
- $\quad$ Basic factor structure holds for all groups, relationship between factors and items are equivalent and partial invariance is achieved

- $\quad$ Participants were instructed to answer the survey in the same manner in each country

- $\quad$ Measures were statistically tested to determine cross-cultural measure invariance

\section{Multi-group Analysis and Comparisons \\ Data Analysis Design}

- Data analysis techniques were used to control for differences in the samples and measurement error across groups

- $\quad$ Tested for common method bias

- $\quad$ Included control variables to measure observed differences

- Multi-group analysis was conducted using structural equation modeling software. The model was estimated simultaneously for both groups without constraining the measurement errors to test for differences in the coefficient parameters 


\subsection{Survey Scales}

Survey scales were adapted from existing studies in the field of RM $[15,19]$ and buyer-supplier relationships $[16,20,22,28,30,32]$. Scales were designed on a seven-point Likert-scale, anchored with "Strongly Disagree" and "Strongly Agree".

The original English version of the survey was translated into Portuguese and then back-translated by a professional translator and analyzed for any potential discrepancies. The advice of bilingual experts on the meaning of each item was obtained and items were simplified to clarify meaning if needed $[38,42]$. The surveys were pre-tested with practitioners prior to being administered to participants. No concerns were raised about the meaning of the items during the pilot tests, suggesting that the survey questions were equally understood and accepted in both countries. The final survey items are listed on Table 2.

Table 2. Scale Items.

\begin{tabular}{|c|}
\hline Relationship Benefits (Functional)-Reynolds and Beatty, 1999 \\
\hline $\begin{array}{l}\text { We value the convenience benefits this supplier provides us very highly } \\
\text { We value the time saving benefits this supplier provides us very highly } \\
\text { We benefit from the advice that this supplier gives us } \\
\text { We make better purchase decisions because of this supplier }\end{array}$ \\
\hline Relationship Benefits (Social) -Reynolds and Beatty, 1999 \\
\hline $\begin{array}{l}\text { The friendship aspect of our relationship with this supplier is very important to us } \\
\text { We enjoy spending time with this supplier } \\
\text { We value the close, personal relationship we have with this supplier } \\
\text { We enjoy this supplier's company }\end{array}$ \\
\hline Information Exchange-Mohr and Spekman, 1994; Anderson and Weitz, 1992 \\
\hline $\begin{array}{c}\text { We keep this supplier well informed about what is going on in our company } \\
\text { We seek the advice of this supplier when planning our operations } \\
\text { We set goals together with this supplier } \\
\text { We listen and incorporate suggestions given by this supplier }\end{array}$ \\
\hline Cooperation-Anderson and Narus, 1990 \\
\hline $\begin{array}{l}\text { This supplier helps our company out in whatever ways we ask } \\
\text { Our company helps this supplier in whatever ways they ask }\end{array}$ \\
\hline Benevolent Trust-Doney and Cannon, 1997 \\
\hline $\begin{array}{l}\text { This supplier is genuinely concerned that our business succeeds } \\
\text { We trust that this supplier keeps our best interests in mind } \\
\text { When making important decisions, this supplier considers our welfare as well as its own }\end{array}$ \\
\hline Performance Satisfaction-Barry and Doney, 2011 \\
\hline $\begin{array}{c}\text { The performance by this supplier meets our expectations } \\
\text { The performance by this supplier leads to desired results } \\
\text { The turnaround time for work performed by this supplier meets our expectations } \\
\text { Compared to alternative suppliers, we are confident this supplier will better help us accomplish } \\
\text { our goals }\end{array}$ \\
\hline
\end{tabular}

Our loyalty to this supplier is a major reason why we continue to work with this supplier We want to stay associated with this supplier because of our allegiance to them

We intend to continue working with this supplier because we feel they are "part of the family" Items have been adapted to fit the context of the study.

\subsection{Population and Sample}

Data were collected from a sample of owners, managers and buyers of organizations that operate in the United States and in Brazil. Participants belonged to the local Chambers of Commerce in each country and shared common job titles and responsibilities [42]. In the United States, data were collected primarily via the online version of the survey with 
a response rate of $13.2 \%$. This rate is considered standard in business-to-business study context. However, in Brazil, the online response rates were insufficiently low. Based on Chamber officials' recommendations, the paper version of the survey was delivered in person to address local practice in this country to conduct business face-to-face [38]. Upon testing for differences in the means of early versus late as well as online versus paper respondents, no significant differences were found [43]. The final sample sizes were as follows: US ( $n=169)$ and Brazil $(n=110)$. The distribution of the samples is summarized in Table 3.

Table 3. Demographic sample distribution.

\begin{tabular}{ccccccccc}
\hline \multirow{2}{*}{$\begin{array}{c}\text { Country } \\
\text { Sample }\end{array}$} & \multicolumn{3}{c}{ Length of Relationship (\%) } & \multicolumn{2}{c}{ Job Task (\%) } & \multicolumn{2}{c}{ Firm's Main Offering (\%) } \\
\cline { 2 - 9 } & $\mathbf{1 - 5}$ & $\mathbf{6 - 1 0}$ & $\mathbf{1 1}$ or $>$ & Buyer & $\begin{array}{c}\text { Non- } \\
\text { buyer }\end{array}$ & Product & Service & Both \\
\hline U.S. & 39.05 & 37.87 & 23.08 & 82.80 & 17.20 & 33.10 & 42.10 & 24.80 \\
Brazil & 47.27 & 31.82 & 20.91 & 80.00 & 20.00 & 44.50 & 38.20 & 17.30 \\
\hline
\end{tabular}

\subsection{Measurement, Validity and Reliability}

The internal consistency and validity of the scales within each country sample were assessed by analyzing the composite reliability for each scale. The measures demonstrate excellent properties as the composite reliability for each scale in all three samples exceeds 0.70 [37]. The average variance extracted (AVE) provides evidence of convergent validity as measures have an AVE exceeding the recommended threshold of 0.50 [44]. Table 4 summarizes the reliability and validity tests for the final scales in the study.

Table 4. Reliability and validity tests for measures.

\begin{tabular}{ccccccccc}
\hline & \multicolumn{3}{c}{ U.S. } & \multicolumn{5}{c}{ Brazil } \\
\hline Variable & Mean & SD & CR & AVE & Mean & SD & CR & AVE \\
\hline Functional Benefits & 5.43 & 1.09 & 0.91 & 0.72 & 5.28 & 0.93 & 0.78 & 0.54 \\
\hline Social Benefits & 4.99 & 1.39 & 0.92 & 0.75 & 3.58 & 1.52 & 0.82 & 0.55 \\
\hline $\begin{array}{c}\text { Information } \\
\text { Exchange }\end{array}$ & 5.43 & 1.00 & 0.91 & 0.72 & 5.26 & 1.00 & 0.81 & 0.53 \\
\hline Cooperation & 5.00 & 1.34 & 0.91 & 0.83 & 4.60 & 1.55 & 0.89 & 0.81 \\
\hline Benevolent Trust & 5.48 & 1.15 & 0.89 & 0.74 & 4.86 & 1.44 & 0.88 & 0.72 \\
\hline Commitment & 5.67 & 0.96 & 0.90 & 0.75 & 5.51 & 1.01 & 0.87 & 0.70 \\
\hline $\begin{array}{c}\text { Performance } \\
\text { Satisfaction }\end{array}$ & 5.18 & 1.28 & 0.92 & 0.74 & 4.58 & 1.58 & 0.86 & 0.61 \\
\hline
\end{tabular}

Note: SD Standard Deviation; CR Composite Reliability as Cronbach's Alpha; AVE Average Variance Extracted.

To further assess convergent validity, a confirmatory factor analysis was conducted and the overall fit of the measurement model is excellent $\left(\chi^{2}(279)=1038.784, p<0.01\right.$; $\mathrm{CFI}=0.95 ; \mathrm{IFI}=0.95 ; \mathrm{TLI}=0.90 ; \mathrm{RMSEA}=0.09$ ). The correlation matrix for the two samples, shown in Table 5, demonstrates evidence of discriminant validity as the correlations between the same variables are larger than the correlations between distinct variables [45]. 
Table 5. Correlation matrix.

\begin{tabular}{cccccccc}
\hline Variables & FB & SB & IE & CO & BT & PS & CM \\
\hline \multirow{2}{*}{ Functional Benefits (FB) } & 0.85 & & & & & & \\
& 0.76 & & & & & & \\
\hline \multirow{2}{*}{ Social Benefits (SB) } & 0.73 & 0.87 & & & & & \\
& 0.52 & 0.75 & & & & & \\
\hline \multirow{2}{*}{ Information Exchange (IE) } & 0.62 & 0.82 & 0.85 & & & & \\
& 0.60 & 0.47 & 0.73 & & & & \\
\hline \multirow{2}{*}{ Cooperation (CO) } & 0.81 & 0.75 & 0.75 & 0.91 & & & \\
& 0.58 & 0.40 & 0.43 & 0.90 & & & \\
\hline \multirow{2}{*}{ Benevolent Trust (BT) } & 0.80 & 0.70 & 0.70 & 0.82 & 0.86 & & \\
& 0.74 & 0.62 & 0.61 & 0.76 & 0.85 & & \\
\hline \multirow{2}{*}{ Performance Satisfaction (PS) } & 0.80 & 0.57 & 0.50 & 0.65 & 0.84 & 0.86 & \\
& 0.68 & 0.33 & 0.33 & 0.66 & 0.75 & 0.78 & \\
\hline \multirow{2}{*}{ Commitment (CM) } & 0.73 & 0.79 & 0.66 & 0.78 & 0.73 & 0.65 & 0.86 \\
\hline
\end{tabular}

Notes: All correlations are significant at $p<0.01$; Top correlations: US sample; bottom correlations: Brazil sample.

Given the systematic nature of the survey, the following procedures were taken in order to decrease the potential for common method variance in this study. First, participants were assured that the survey was confidential, voluntary, without a right or wrong answer and conducted solely for the purposes of academic research. Items were simplified and reworded to remove ambiguity whenever necessary and grouped together when they represented the same variable [46]. To examine measures for a common method variance (CMV), a Harman's single factor test was conducted in SPSS. The total variance explained by loading all items of the model in one single factor extracted was $44.6 \%$, which is lower than the threshold of 50\% [47]. Taken together, common method variance is not expected to be a major concern in this study.

Finally, the factor loadings of items onto each construct are significant and appropriate for both samples and the measurement models demonstrate an adequate level of universal structure to allow for cross-cultural comparisons of the structural model [37,48].

\section{Data Analysis and Results}

Structural equation modeling was used to test the relationships between all constructs in the hypothesized model in Figure 2. The model was estimated simultaneously for the two groups via a multi-group analysis of structural invariance in Amos [49]. The path coefficients were analyzed and statistically compared for significant differences. The invariance in the parameter coefficients for each relationship was used to calculate the critical ratios for differences between parameters matrix to assess the z-scores for the difference of each parameter between groups [49]. The mediating effects of the two relationship connectors (information exchange and mutual cooperation) were tested using a combination of Baron and Kenny [50] and bootstrapping [51].

Results indicate that the model provides excellent explanatory power. Functional and social benefits explain a large portion of information exchange (US $=58 \%$ and Brazil $=47 \%$ ) and mutual cooperation (US $=72 \%$ and Brazil $=42 \%$ ). In turn, the two relationship connectors explain a significant percentage of the variance in benevolent trust (US $=68 \%$ and Brazil $=65 \%$ ). Information exchange is largely responsible for the variance in performance satisfaction in both countries (US $=82 \%$ and Brazil $=79 \%$ ), while benevolent trust and mutual cooperation explain the variance in affective commitment (US $=55 \%$ and $=52 \%$ ).

Most relationships in model are positive and significant supporting all hypotheses with one exception. H3 is partially supported since the influence of social benefits on information exchange is not significant in Brazil. There were a few differences in how affective commitment is established in the US and Brazil. For the US sample, mutual 
cooperation has a greater influence on commitment than in Brazil while benevolent trust has a greater influence commitment in Brazil than in the US. These results provide support for $\mathrm{H} 8 \mathrm{~b}$ and $\mathrm{H} 9 \mathrm{~b}$. Information exchange is also found to have a greater impact on benevolent trust in Brazil than in the US. The invariances in these three path coefficients are statistically significant.

Overall, there are more similarities between the two groups than differences. Functional benefits drive information exchange and mutual cooperation and social benefits foster mutual cooperation in both countries. Information exchange influences benevolent trust and performance satisfaction while mutual cooperation and benevolent trust drive affective commitment equally in the US and Brazil.

The results of the mediating effects of the two relationship connectors (information exchange and mutual cooperation) provide support for hypotheses H10a and H10b. Full mediation is demonstrated when the direct effect of an antecedent on an outcome diminishes to the point of non-significance in the presence of a mediator and the indirect effect is significant. Partial mediation is demonstrated when the direct effect of an antecedent on an outcome diminishes, but it remains significant in the presence of the mediator and the indirect effect is significant. Results show that information exchange partially or fully mediates the relationship between functional benefits and performance satisfaction in both country samples. Mutual cooperation is a partial mediator between social and functional benefits and commitment in the US and also partially mediates social benefits and commitment in Brazil. Overall, results demonstrate support for the role of these two constructs as relationship connectors as proposed by Cannon and Perreault [21].

Finally, the possible influences of length of relationship and the firm's main offering (product vs. service) on commitment were tested on both outcomes and no significant influences were found. A summary of the results is shown in Table 6 and the mediation results are presented in Table 7.

Table 6. Summary of results.

\begin{tabular}{|c|c|c|c|c|c|c|}
\hline \multicolumn{4}{|c|}{ Hypothesized Relationships } & \multirow{2}{*}{$\begin{array}{l}\text { US }(\boldsymbol{\beta}) \\
0.60 * * *\end{array}$} & \multirow{2}{*}{$\begin{array}{c}\text { Brazil }(\boldsymbol{\beta}) \\
0.67^{* * *}\end{array}$} & \multirow{2}{*}{$\begin{array}{r}\text { Z-Score } \\
-1.569\end{array}$} \\
\hline $\mathrm{H}_{1}$ : & Supported & Functional Benefits & Information Exchange & & & \\
\hline $\mathrm{H}_{2}$ : & Supported & Functional Benefits & Mutual Cooperation & $0.49^{* * *}$ & $0.45^{* * *}$ & -0.942 \\
\hline $\mathrm{H}_{3}:$ & $\begin{array}{l}\text { Partially } \\
\text { Supported }\end{array}$ & Social Benefits & Information Exchange & $0.20 * * *$ & 0.05 & 1.629 \\
\hline $\mathrm{H}_{4}:$ & Supported & Social Benefits & Mutual Cooperation & $0.42^{* * *}$ & $0.32^{* * *}$ & 0.732 \\
\hline $\mathrm{H}_{5}:$ & Supported & Information Exchange & Benevolent Trust & $0.47^{* * *}$ & $0.52^{* * *}$ & $-1.786^{*}$ \\
\hline $\mathrm{H}_{6}$ : & Supported & Information Exchange & $\begin{array}{l}\text { Performance } \\
\text { Satisfaction }\end{array}$ & $0.91^{* * *}$ & $0.89 * * *$ & -1.212 \\
\hline $\mathrm{H}_{7}:$ & Supported & Mutual Cooperation & Benevolent Trust & $0.45^{* * *}$ & $0.43^{* * *}$ & -0.087 \\
\hline $\mathrm{H}_{8 \mathrm{a}, \mathrm{b}}$ : & Supported & Mutual Cooperation & Affective Commitment & $0.47^{* * *}$ & $0.19 * *$ & $2.262 * *$ \\
\hline $\mathrm{H}_{9 \mathrm{a}, \mathrm{b}}$ : & Supported & Benevolent Trust & Affective Commitment & $0.33^{* * *}$ & $0.59^{* * *}$ & $-2.187^{* *}$ \\
\hline \multicolumn{4}{|c|}{ Model Statistics } & US & \multicolumn{2}{|c|}{ Brazil } \\
\hline \multicolumn{4}{|c|}{$\mathrm{R}^{2}$ for Information Exchange } & 0.58 & \multicolumn{2}{|c|}{0.47} \\
\hline \multicolumn{4}{|c|}{$\mathrm{R}^{2}$ for Mutual Cooperation } & 0.72 & \multicolumn{2}{|c|}{0.42} \\
\hline \multicolumn{4}{|c|}{$\mathrm{R}^{2}$ for Benevolent Trust } & 0.68 & \multicolumn{2}{|c|}{0.65} \\
\hline \multicolumn{4}{|c|}{$\mathrm{R}^{2}$ for Performance Satisfaction } & 0.82 & \multicolumn{2}{|c|}{0.79} \\
\hline \multicolumn{4}{|c|}{$\mathrm{R}^{2}$ for Affective Commitment } & 0.55 & \multicolumn{2}{|c|}{0.52} \\
\hline
\end{tabular}

Notes: ${ }^{* * *} p$-value $<0.01 ;{ }^{* *} p$-value $<0.05 ;{ }^{*} p$-value $<0.10 ; \beta=$ standardized parameter estimates; $\mathrm{Z}=$ critical ratio scores. 
Table 7. Mediation results.

\begin{tabular}{|c|c|c|c|}
\hline $\begin{array}{c}\text { Mediator } \\
\text { Information Exchange }\end{array}$ & $\begin{array}{l}\text { Direct Effects ( } \beta \text { ) } \\
\text { Without Mediator } \\
\text { US-Brazil }\end{array}$ & $\begin{array}{l}\text { Direct Effects ( } \beta \text { ) } \\
\text { With Mediator } \\
\text { US-Brazil }\end{array}$ & $\begin{array}{l}\text { Indirect Effects }(\beta) \\
\text { Type of Mediation } \\
\text { US-Brazil }\end{array}$ \\
\hline $\begin{array}{c}\text { Relationship } \\
\text { Functional Benefit } \rightarrow \text { Performance } \\
\text { Satisfaction }\end{array}$ & $0.73^{* * *} ; 0.63^{* * *}$ & $0.19^{* * *} ; 0.05$ & $\begin{array}{l}\quad p=0.005 ; p=0.006 \\
\text { US }=\text { Partial Mediation } \\
\text { Brazil = Full Mediation }\end{array}$ \\
\hline $\begin{array}{c}\text { Relationship } \\
\text { Social Benefit } \rightarrow \text { Performance } \\
\text { Satisfaction }\end{array}$ & $-0.02 ; 0.01$ & $-0.21^{* * *} ;-0.03$ & $\begin{array}{c}p=0.032 ; p=0.508 \\
\text { US = No Mediation } \\
\text { Brazil = No Mediation }\end{array}$ \\
\hline $\begin{array}{c}\text { Mediator } \\
\text { Mutual Cooperation }\end{array}$ & $\begin{array}{c}\text { Direct Effects }(\beta) \\
\text { Without Mediator } \\
\text { US-Brazil }\end{array}$ & $\begin{array}{l}\text { Direct Effects ( } \beta \text { ) } \\
\text { With Mediator } \\
\text { US-Brazil }\end{array}$ & $\begin{array}{l}\text { Indirect Effects }(\beta) \\
\text { Type of Mediation } \\
\text { US-Brazil }\end{array}$ \\
\hline $\begin{array}{c}\text { Relationship } \\
\text { Functional Benefit } \rightarrow \text { Affective } \\
\text { Commitment }\end{array}$ & $0.38^{* * *} ; 0.11$ & $0.29^{* * *} ; 0.09$ & $\begin{array}{l}\quad p=0.02 ; p=0.015 \\
\text { US }=\text { Partial Mediation } \\
\text { Brazil = No Mediation }\end{array}$ \\
\hline $\begin{array}{l}\text { Relationship } \\
\text { Social Benefit } \rightarrow \text { Affective } \\
\text { Commitment }\end{array}$ & $0.29^{* * *} ; 0.23^{* * *}$ & $0.21^{* * *} ; 0.21^{* * *}$ & $\begin{array}{c}\quad p=0.019 ; p=0.013 \\
\text { US }=\text { Partial Mediation } \\
\text { Brazil }=\text { Partial Mediation }\end{array}$ \\
\hline
\end{tabular}

Notes: ${ }^{* * *} p<0.01 ; \beta=$ standardized parameter estimates; $p=$ Significance.

\section{Discussion and Implications}

There is growing consensus among scholars and practitioners alike regarding the importance of adopting PSS strategies to differentiate and gain a competitive advantage "in an increasingly globalized market" [7]. For both product and service providers, PSS models provide sustainable opportunities to focus on result-oriented offerings with unique bundle solutions to customers and create additional value that are difficult to be imitated by the competitors [5]. It is becoming increasingly difficult to differentiate based on functional services alone as they have become standard or 'basic' in most industries. By implementing a combination of functional and social benefits to its main offering, firms create distinct solution outcomes to fulfill customer's needs in a more personal manner. In that light, PSS strategies are marketing strategies that can help firms establish stronger relationships with customers that can lead to more trusted, satisfied and committed relationships-the tenets of relationship marketing. Therefore, this research set out to bridge the two fields (PSS and RM) by proposing and testing a PSS framework within the context of relationship marketing based on the delivery of unique functional and social benefits to increase cooperation and information exchange, build relationship capital and foster sustainable partnerships. In addition, given the global nature of competition today, the framework is tested for its generalizability in two institutional and economically distinct country contexts.

The results demonstrate the relevance of the framework in both the US and Brazil with few differences. Universally, firms can focus on providing both functional benefits to help buyers in a convenient way that include time-saving activities and advice. These additional services will help buyers make better decisions and improve the daily operations. As a way to further differentiate their bundle offering, firms can also focus on social benefits and the personal and friendly aspect of their relationship with buyers. Results show that buyers enjoy and value the close ties formed with their suppliers and welcome more time spent in social settings, especially when mutually cooperating. It is difficult for competitors to replicate these intangible benefits, so firms can invest in resources to create opportunities for social gatherings and train sellers on how to cultivate a more personal and friendly atmosphere with the buyer. Combined, these relationship benefits form a seamless offering that greatly contributes to improve the level of information exchange and mutual cooperation between partners.

The results clearly demonstrate that partners welcome open communication and expect a degree of collaboration typical of relational exchanges. Firms are expected to 
give advice and suggestions to buyers and help them set goals. The open exchange of information create knowledge and intangible assets for both partners that are co-created, unique to the partnership and sources of competitive advantage to the buyer and supplier alike [6]. Most of all, open communication signals to buyers that suppliers are customeroriented, that they have the buyer's best interest in mind and increase the buyer's trust in the provider. One of the most striking revelation of this study is the direct positive effect that information-exchange has on increasing the buyer's satisfaction with the supplier's performance. A firm can focus on open communication to meet or succeed buyer's expectations and to demonstrate to buyers the emphasis placed on helping them achieve their desired goals as noted by Sakyi-Gyinae and Holmlund [7]. Mutual cooperation increases trust in the relationship and shows the supplier's concern with the buyer's welfare. Mutual cooperation also increases the buyer's desire to stay loyal to the partnership. Buyers demonstrate their affective allegiance to the partnership and consider the supplier as 'part of the family'. In the US, mutual cooperation is the most important strategy to increase the buyer's commitment in the supplier. Trust is also found to foster commitment. Trusted relationships are more likely to be successful and sustainable. In Brazil, trust is the most important factor for buyer's when deciding to commit to the supplier. Despite these two distinct country emphases on the commitment-building process observed in this study's results, overall the framework is found to be universally relevant in both country contexts.

\section{Limitations and Future Research}

The first limitation of the study is the two-country sample. Despite being representative of two distinct country contexts (US $=$ developed market vs. Brazil $=$ emerging market), results cannot be generalized to similar market contexts without considering other institutional and cultural factors. Second, despite the rigor of the survey methodology and all precautions taken to purify the scale and validate the Portuguese translated version, misinterpretation of some survey questions cannot be ruled out. Since the original items were written in English based on items developed by North American authors, some interpretation issues may have occurred among Brazilian respondents. Last, this study represents a snapshot of the sustainable B2B relationship building process; thus the results are not generalizable in a longitudinal manner.

There are several research opportunities that can be explored as a result of this study. PSS will continue to be more relevant and important in both developing and emerging markets as sustainable strategies for partnership formation will rely on more complex business models. Researchers are encouraged to further examine PSS frameworks within other RM models. There are several additional factors that foster relationship capital and can improve the relationship quality of partners. Communication quality, conflict resolution and similarity are a few other aspects of relational exchanges that could be considered when studying B2B partnership and sustainability. Finally, researchers are encouraged to replicate this study and include other country samples to test for the generalizability of this PSS framework.

Funding: This research received no external funding.

Institutional Review Board Statement: The study was conducted according to the guidelines of the Declaration of Helsinki, and approved by the Institutional Review Board of Nova Southeastern University (IRB \#091203, approved on 11 September 2012).

Informed Consent Statement: Informed consent was obtained from all subjects involved in the study.

Data Availability Statement: The data used to support the results of this study are available from the corresponding author upon request.

Acknowledgments: This study was supported by Eckerd College.

Conflicts of Interest: The author declares no conflict of interest. 


\section{References}

1. Neely, A.; Benedettini, O.; Visnjic, I. The servitization of manufacturing: Further evidence. In Proceedings of the 18th European operations management association conference, Cambridge, UK, 1-3 July 2011; 2011.

2. Kryvinska, N.; Kaczor, S.; Strauss, C.; Greguś, M. Servitization Strategies and Product-Service-Systems. In Proceedings of the 2014 IEEE World Congress on Services, Anchorage, AK, USA, 27 June-2 July 2014; pp. 254-260.

3. Baines, T.S.; Lightfoot, H.W.; Evans, S.; Neely, A.; Greenough, R.; Peppard, J.; Roy, R.; Shehab, E.; Braganza, A.; Tiwari, A.; et al. State-of-the-art in product-service systems. Proc. Inst. Mech. Eng. Part. B: J. Eng. Manuf. 2007, 221, 1543-1552. [CrossRef]

4. Baines, T.S.; Lightfoot, H.W.; Benedettini, O.; Kay, J.M. The servitization of manufacturing: A review of literature and reflection on future challenges. J. Manuf. Technol. Manag. 2009. [CrossRef]

5. Parida, V.; Wincent, J. Why and how to compete through sustainability: A review and outline of trends influencing firm and network-level transformation. Int. Entrep. Manag. J. 2019, 15, 1-19. [CrossRef]

6. Gupta, S.; Polonsky, M. Understanding the spill-over effect of value co-creation in buyer-supplier interactions: A strategic view. J. Bus. Ind. Mark. 2020. [CrossRef]

7. Sakyi-Gyinae, K.; Holmlund, M. What Do Business Customers Value? An Empirical Study of Value Propositions in a Servitization Context. Technol. Innov. Manag. Rev. 2018, 8, 36-43. [CrossRef]

8. Bastl, M.; Johnson, M.; Lightfoot, H.; Evans, S. Buyer-supplier relationships in a servitized environment. Int. J. Oper. Prod. Manag. 2012, 32, 650-675. [CrossRef]

9. Marić, J.; Opazo-Basáez, M. Green Servitization for Flexible and Sustainable Supply Chain Operations: A Review of Reverse Logistics Services in Manufacturing. Glob. J. Flex. Syst. Manag. 2019, 20, 65-80. [CrossRef]

10. Reim, W.; Parida, V.; Örtqvist, D. Product-Service Systems (PSS) business models and tactics-a systematic literature review. J. Clean. Prod. 2015, 97, 61-75. [CrossRef]

11. Vandermerwe, S.; Rada, J. Servitization of business: Adding value by adding services. Eur. Manag. J. 1988, 6, 314-324. [CrossRef]

12. Graca, S.S.; Barry, J.M.; Doney, P.M. Performance outcomes of behavioral attributes in buyer-supplier relationships. J. Bus. Ind. Mark. 2015, 30, 805-816. [CrossRef]

13. Gebauer, H.; Binz, C. Regional benefits of servitization processes: Evidence from the wind-to-energy industry. Reg. Stud. 2018, 53, 366-375. [CrossRef]

14. Lambe, C.J.; Wittmann, C.M.; Spekman, R.E. Social Exchange Theory and Research on Business-to-Business Relational Exchange. J. Business-to-Business Mark. 2001, 8, 1-36. [CrossRef]

15. Morgan, R.M.; Hunt, S.D. The commitment-trust theory of relationship marketing. J. Mark. 1994, 58, 20-38. [CrossRef]

16. Reynolds, K.E.; Beatty, S.E. Customer benefits and company consequences of customer-salesperson relationships in retailing. $J$. Retail. 1999, 75, 11-32. [CrossRef]

17. Hennig-Thurau, T.; Gwinner, K.P.; Gremler, D.D. Understanding relationship marketing outcomes: An integration of relational benefits and relationship quality. J. Serv. Res. 2002, 4, 230-247. [CrossRef]

18. Graça, S.S.; Barry, J.M.; Doney, P.M. B2B commitment building in emerging markets: The case of Brazil. J. Pers. Sell. Sales Manag. 2016, 36, 105-125. [CrossRef]

19. Palmatier, R.W.; Dant, R.P.; Grewal, D.; Evans, K.R. Factors Influencing the Effectiveness of Relationship Marketing: A MetaAnalysis. SSRN Electron. J. 2006, 70, 136-151.

20. Mohr, J.; Spekman, R. Characteristics of partnership success: Partnership attributes, communication behavior, and conflict resolution techniques. Strat. Manag. J. 1994, 15, 135-152. [CrossRef]

21. Cannon, J.P.; Perreault, W.D. Buyer-Seller Relationships in Business Markets. J. Mark. Res. 1999, 36, 439-460.

22. Anderson, J.C.; Narus, J.A. A model of distributor firm and manufacturer firm working partnerships. J. Mark. 1990, 54, 42-58. [CrossRef]

23. Karatzas, A.; Johnson, M.; Bastl, M. Manufacturer-supplier relationships and service performance in service triads. Int. J. Oper. Prod. Manag. 2017, 37, 950-969. [CrossRef]

24. Smith, J.B.; Barclay, D.W. Selling partner relationships: The role of interdependence and relative influence. J. Pers. Sell. Sales Manag. 1999, 19, 21-40.

25. Anderson, E.; Weitz, B. The use of pledges to build and sustain commitment in distribution channels. J. Mark. Res. 1992, 29, 18-34. [CrossRef]

26. Robson, M.J.; Skarmeas, D.; Spyropoulou, S. Behavioral attributes and performance in international strategic alliances. Int. Mark. Rev. 2006, 23, 585-609. [CrossRef]

27. Doney, P.M.; Barry, J.M.; Abratt, R. Trust determinants and outcomes in global B2B services. Eur. J. Mark. 2007, 41, 1096-1116. [CrossRef]

28. Barry, J.M.; Doney, P.M. Cross-Cultural Examination of Relationship Quality. J. Glob. Mark. 2011, 24, 305-323. [CrossRef]

29. Barry, J.M.; Graca, S.S. Moderating effects of institutional factors on relationship quality: A comparative analysis of the US, Brazil, and China. J. Bus. Ind. Mark. 2019, 34, 1339-1359. [CrossRef]

30. Doney, P.M.; Cannon, J.P. An examination of the nature of trust in buyer-seller relationships. J. Mark. 1997, 61, 35-51.

31. Barringer, B.R. The effects of relational channel exchange on the small firm: A conceptual framework. J. Small Bus. Manag. 1997, 35, 65-79.

32. Anderson, E.; Weitz, B. Determinants of continuity in conventional industrial channel dyads. Mark. Sci. 1989. [CrossRef] 
33. Graça, S.S.; Kharé, V.P. Building social-capital networks and relationship commitment in China and India. Eur. Bus. Rev. 2020, 32, 823-843. [CrossRef]

34. Li, S. Managing international business in relation-based versus rule-based countries; Business Expert Press: New York, NY, USA, 2009.

35. Rottig, D. Institutions and emerging markets: Effects and implications for multinational corporations. Int. J. Emerg. Mark. 2016, 11, 2-17. [CrossRef]

36. Dwyer, R.F.; Schurr, P.H.; Oh, S. Developing Buyer-Seller Relationships. J. Mark. 1987, 51, 11-27. [CrossRef]

37. Hair, J.F.; Black, W.C.; Babin, B.J.; Anderson, R.E. Multivariate Data Analysis; Pearson Prentice Hall: Upper Saddle River, NJ, USA, 2010.

38. Malhotra, N.K.; Agarwal, J.; Petersen, M. Methodological issues in cross-cultural marketing research: A state-of-the-art review. Ind. Mark. Rev. 1996, 13, 7-43. [CrossRef]

39. Steenkamp, J.-B.E.M.; Baumgartner, H. Assessing Measurement Invariance in Cross-National Consumer Research. J. Consum. Res. 1998, 25, 78-90. [CrossRef]

40. Reynolds, N.L.; Simintiras, A.C.; Diamantopoulos, A. Theoretical justification of sampling choices in international marketing research: Key issues and guidelines for researchers. J. Int. Bus. Stud. 2002, 34, 80-89. [CrossRef]

41. Cannon, J.P.; Doney, P.M.; Mullen, M.R.; Petersen, K.J. Building long-term orientation in buyer-supplier relationships: The moderating role of culture. J. Oper. Manag. 2010, 28, 506-521. [CrossRef]

42. Czinkota, M.R.; Hand, M.J.; Douglas, S.P.; Craig, C.S. International Marketing Research. J. Mark. Res. 1984, 21, 120. [CrossRef]

43. Armstrong, S.J.; Overton, T.S. Estimating nonresponse bias in mail surveys. J. Mark. Res. 1977, 14, 396-402. [CrossRef]

44. Fornell, C.; Lacker, D.F. Structural equation models with unobservable variables and measurement error: Algebra and statistics. J. Mark. Res 1981, 18, 382-388. [CrossRef]

45. Churchill, G.A. A Paradigm for Developing Better Measures of Marketing Constructs. J. Mark. Res. 1979, 16, 64. [CrossRef]

46. Podsakoff, P.M.; MacKenzie, S.B.; Lee, J.-Y.; Podsakoff, N.P. Common method biases in behavioral research: A critical review of the literature and recommended remedies. J. Appl. Psychol. 2003, 88, 879. [CrossRef]

47. MacKenzie, S.B.; Podsakoff, P.M. Common Method Bias in Marketing: Causes, Mechanisms, and Procedural Remedies. J. Retail. 2012, 88, 542-555. [CrossRef]

48. MacKenzie, S.B. Podsakoff Construct Measurement and Validation Procedures in MIS and Behavioral Research: Integrating New and Existing Techniques. MIS Q. 2011, 35, 293. [CrossRef]

49. Byrne, B.M. Testing for Multigroup Invariance Using AMOS Graphics: A Road Less Traveled. Struct. Equ. Model. A Multidiscip. J. 2004, 11, 272-300. [CrossRef]

50. Baron, R.M.; Kenny, D.A. The moderator-mediator variable distinction in social psychological research: Conceptual, strategic, and statistical considerations. J. Pers. Soc. Psychol. 1986, 51, 1173-1182. [CrossRef] [PubMed]

51. Preacher, K.J.; Hayes, A.F. Asymptotic and resampling strategies for assessing and comparing indirect effects in multiple mediator models. Behav. Res. Methods 2008, 40, 879-891. [CrossRef] [PubMed] 